\title{
Prevalence of Helicobacter pylori infection, its correlation with gastroduodenal diseases and the incidence of gastric cancer in Nepal
}

\author{
Umid Kumar Shrestha, ${ }^{\mathrm{a}, \mathrm{b}^{*}}$ Arnab Ghosh, ${ }^{\mathrm{c}}$ Vijay M Alurkar, ${ }^{\mathrm{a}}$ Suresh C Kohli, ${ }^{\mathrm{a}}$ Subash Sapkota ${ }^{\mathrm{a}, \mathrm{b}}$ \\ ${ }^{a}$ Deparment of Medicine, Manipal College of Medical Sciences and Manipal Teaching Hospital, Pokhara, Nepal \\ ${ }^{b}$ Deparment of Medicine, Kaski Sewa Hospital and Research Center, Pokhara, Nepal \\ ${ }^{c}$ Department of Pathology, Manipal College of Medical Sciences and Manipal Teaching Hospital, Pokhara, Nepal
}

\author{
Accepted on \\ June 27th 2013 \\ Dol Name \\ http://dx.doi.org/10.3126/jaim.v2i2.8777

\section{Keywords} \\ Prevalence, H. pylori, incidence, \\ gastric cancer, Nepal

\section{Citation} \\ Umid Kumar Shrestha, Arnab Ghosh, Vijay M \\ Alurkar, Suresh C Kohli, Subash Sapkota. Prevalence \\ of Helicobacter pylori infection, its correlation with \\ gastroduodenal diseases and the incidence of \\ gastric cancer in Nepal. Journal of Advances in \\ Internal Medicine 2013;02(02):52-60.
}

\begin{abstract}
Background and aims: The Helicobacter pylori (H. pylori) prevalence in Asian countries is highly variable, with higher seroprevalence shown in the previous studies of developing Asian countries. We aimed to determine the current H. pylori prevalence, correlate with gastroduodenal diseases and study gastric cancer incidence in Nepal.
\end{abstract}

Methods: Among 3357 patients referred for endoscopy, 2820 eligible patients underwent upper gastrointestinal endoscopy with biopsy; H. pylori was considered positive when either of Rapid Urease Test (RUT) or histopathology showed positive result.

Results: The $H$. pylori prevalence was $29.4 \%$ in overall distribution, $41.1 \%$ in gastritis and or duodenitis, $69.5 \%$ in gastric ulcer, $84.7 \%$ in duodenal ulcer, $20.8 \%$ in gastric polyp and $11.5 \%$ in gastric cancer. The $H$. pylori infection was significantly associated with gastritis and or duodenitis $[\mathrm{P}<0.001$; Odds Ratio (OR) 1.53, 95\% Confidence Interval ( $\mathrm{Cl}$ ) 1.47-1.59], gastric ulcer $(\mathrm{P}<0.001$; OR 18.62, 95\% Cl 12.40-27.81), duodenal ulcer ( $P<0.001$; OR 48.89, 95\% Cl 25.2394.75), gastric polyp ( $P=0.001 ; O R 7.66,95 \% \mathrm{Cl} 3.18-18.44)$ and gastric cancer $(P=0.005 ;$ OR 3.78, 95\% Cl 1.82-7.86). The age-standardized (world) annual rate of gastric cancer in Kaski district of Nepal was 3.3 per 100,000.

Conclusions: The H. pylori prevalence in Nepal was lower than that shown in the previous studies of developing Asian countries, but was significantly high in gastritis and or duodenitis, and peptic ulcers. Similarly, the gastric cancer incidence was also low in Nepal and was significantly associated with $\mathrm{H}$. pylori. Further study is needed to establish the association of $H$. pylori with gastric cancer in Nepal.

\section{INTRODUCTION}

It is estimated that one-half or more of the world's adult population has Helicobacter pylori (H. pylori) infection. ${ }^{1}$ The prevalence of $H$. pylori infection and its related diseases in various Asian countries is highly variable, with higher prevalence shown in developing Asian countries, but there has been only limited information available regarding the actual distribution of $H$. pylori. The $H$. pylori infection has been linked with peptic ulcer disease, non-cardia gastric adenocarcinomas and gastric mucosa associated lymphoid tissue (MALT) lymphomas. ${ }^{2-6}$ The World Health Organization and International Agency for Research on Cancer consensus group classified H. pylori as a definite carcinogen. ${ }^{7}$

\footnotetext{
* Corresponding author Umid Kumar Shrestha, MD, PhD Department of Medicine Manipal College of Medical Sciences, Pokhara, Nepal Email: umidshrestha@gmail.com
} 
However, the low rate of gastric cancer incidence was noted with high prevalence of $H$. pylori infection in India, Philippines, or Thailand; on the other hand, the high rate of gastric cancer incidence was observed in Japan and Korea with variable prevalence of $H$. pylori. ${ }^{8-10}$ The study suggests that $H$. pylori infection is not the only factor related to gastric cancer risk. ${ }^{11,12}$ This Asian enigma could be because of the influence of other variables such as bacterial virulence factors, concomitant environmental factors, host susceptibility and immune response. Nevertheless, the significance of the association of $H$. pylori with gastric cancer cannot be underestimated. The aims of our study were to determine the prevalence of $H$. pylori infection, correlate its association with related gastroduodenal diseases and find out the incidence rate of gastric cancer in Nepal.

\section{METHODS}

Among a total of 3357 patients referred for upper gastrointestinal (GI) endoscopy, only 2820 patients were eligible for the study. The exclusion criteria for the study were: 1) patients who had received proton pump inhibitors or histamine 2-receptor antagonists for a minimum of 2 weeks and antibiotics for 4 weeks prior to the enrollment in the study; $^{13}$ patients who had Antacid, Bismuth, Non-steroidal anti-inflammatory drugs or had triple therapy of $H$. pylori eradication in the past, 2) patients with a diagnosis of portal hypertensive gastropathy, esophageal varices and hepatic encephalopathy, 3) patients with an abnormal coagulation profile, 4) patients with severe co-morbid conditions such as heart failure, kidney failure, etc. and 5) patients not giving an informed consent for the study.

All eligible 2820 subjects underwent upper GI endoscopy at the tertiary referral hospital of western region of Nepal at Manipal Teaching Hospital and Kaski Sewa Hospital, located at Pokhara city of Kaski district of Nepal during a period of May 2010 to April 2013. Some patients diagnosed of having gastric cancer were received from other local hospitals (Western Regional Hospital and Gandaki Medical College) of Kaski, Nepal. Nepal is a developing country of South Asia with a population of $26,494,504$ and Kaski is a district of western region of Nepal with a population of 462,098 with an altitude of 1178 meters $(m) .{ }^{14}$ The annual incidence rate of gastric cancer was determined per 100,000 world population by enumerating all new gastric cancer patients in Kaski district during the three year period (2010 - 2013); in addition to the crude annual rate of gastric cancer, the age-adjusted (world) incidence rate was also calculated according to the population of Kaski district of Nepal and world in different age groups. ${ }^{14,15}$

The informed consent was taken from all study subjects and the study protocol was approved by the ethics committees of the participating centers.

Biopsies from the antrum, corpus and fundus of the stomach were taken for Rapid Urease Test (RUT) and histopathology. The RUT was done by placing the biopsy specimen into test gel and the color changed into red in $20 \mathrm{~min}$ to 24 hours time was regarded as a positive result, after incubating the gastric tissue into the test gel at the room temperature.

In all the patients, three endoscopic biopsies taken from the stomach were sent in $10 \%$ formalin or Bouin's fluid for histopathology. The tissue biopsies were routinely processed. At least three sections from each tissue biopsy in each case were studied. Sections were of 3 micron thickness. All the tissue had been studied with 2 stains - Hematoxylin-eosin, and Giemsa. The microscopes used were Carl Ziess Axiostar Plus and Olympus CX21. Biopsies were also taken from other representative sites, when endoscopy showed lesions in the oesophagus or duodenum and sent for histopathological examination. The histopathology was used to confirm esophagitis, gastritis and or duodenitis and different neoplastic conditions found during endoscopy.

The H. pylori was considered positive when either of RUT or histopathology (figure 1) showed positive result.

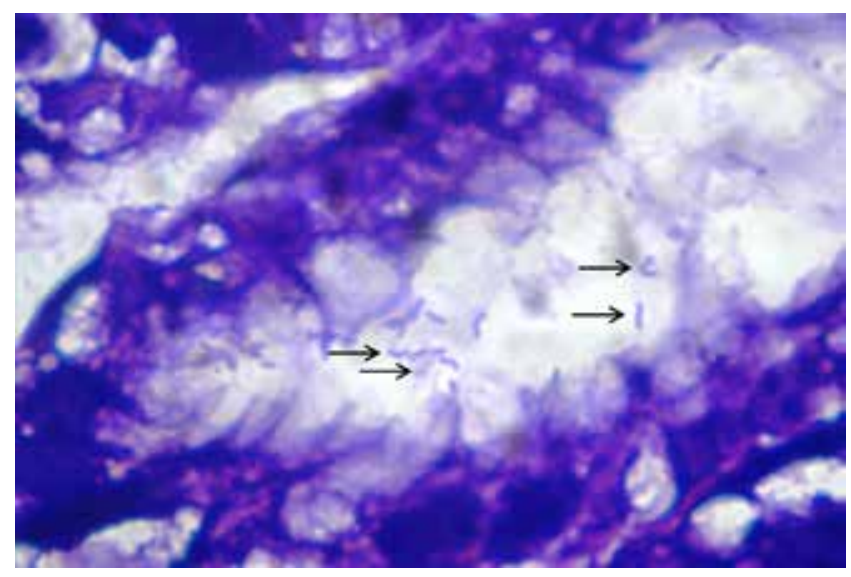

Figure 1: $H$ pylori seen in gastric pits (arrows) , Giemsa , 1000x

All data of endoscopy and the $H$. pylori reports were recorded prospectively. The positive and negative results of $H$. pylori were categorized according to the age group, gender and different diagnosis. All variables of the patients were entered each day into a personal computer and data analysis was performed using SPSS 16.0 software (SPSS Inc., Chicago, IL, USA). All data were analyzed statistically by using Chi-square test or Fisher exact test, Odds Ratio (OR) and 95\% Confidence Interval (Cl), as appropriate. The subjects with normal endoscopic findings were taken as the control group. The $P$ value less than 0.05 was considered to be statistically significant.

\section{RESULTS}

Among 2820 eligible patients, males were 54.2\% and 
females were $45.8 \%$ with the mean age of 46.3 years \pm 17.6 ranging from 8 to 94 years. The distribution of the endoscopic findings was as follows: normal $20.5 \%$, esophagitis $10.2 \%$, gastritis and or duodentis $59.9 \%$, peptic ulcer $5.0 \%$ (gastric ulcer $2.9 \%$, duodenal ulcer $2.1 \%$ ), gastric polyp $0.9 \%$, duodenal polyp $0.2 \%$, esophageal cancer $0.9 \%$, gastric cancer $1.8 \%$, duodenal cancer $0.1 \%$, achalasia cardia $0.1 \%$, hiatus hernia $0.3 \%$, duodenal diverticulum $0.1 \%$ and esophageal stricture $0.1 \%$. The distribution of different diagnosis according to the gender, mean age and age groups is shown in tables 1 and 2.

Table 1: Distribution of different diagnosis according to the gender and mean age

\begin{tabular}{|c|c|c|c|}
\hline Total ( $\mathrm{N}=\mathbf{2 8 2 0}$ ) & $\begin{array}{c}\text { Male } \\
\text { (n=1529) } \\
54 \%\end{array}$ & $\begin{array}{c}\text { Female } \\
(n=1291) \\
45.8 \%\end{array}$ & $\begin{array}{l}\text { Mean Age in } \\
\text { years (Standard } \\
\text { deviation) }\end{array}$ \\
\hline $\begin{array}{l}\text { Normal }(n=578 \\
20.5 \%)\end{array}$ & 278 (48.1\%) & 300 (51.9\%) & $38.6( \pm 15.8)$ \\
\hline $\begin{array}{l}\text { Esophagitis ( } n=287 \text {; } \\
10.2 \% \text { ) }\end{array}$ & 206 (71.8\%) & $81(28.2 \%)$ & $51.7( \pm 16.9)$ \\
\hline $\begin{array}{l}\text { Gastritis and or } \\
\text { duodenitis ( } n=1688 \text {; } \\
59.9 \% \text { ) }\end{array}$ & 866 (51.3\%) & 822 (48.7\%) & $46.5( \pm 17)$ \\
\hline $\begin{array}{l}\text { Gastric ulcer ( } n=82 \text {; } \\
2.9 \%)\end{array}$ & 48 (58.5\%) & $34(41.5 \%)$ & $55.1( \pm 17.6)$ \\
\hline $\begin{array}{l}\text { Duodenal ulcer } \\
(n=59 ; 2.1 \%)\end{array}$ & $44(74.6 \%)$ & $15(25.4 \%)$ & $46.3( \pm 18.7)$ \\
\hline $\begin{array}{l}\text { Gastric polyp }(n=24 ; \\
0.9 \%)\end{array}$ & $12(50 \%)$ & $12(50 \%)$ & $49.0( \pm 18.0)$ \\
\hline $\begin{array}{l}\text { Duodenal polyp }(n=5 \text {; } \\
0.2 \%)\end{array}$ & $4(80 \%)$ & $1(20 \%)$ & $55.4( \pm 5.3)$ \\
\hline $\begin{array}{l}\text { Esophageal cancer } \\
(n=25 ; 0.9 \%)\end{array}$ & 15 (60\%) & $40(0 \%)$ & $\begin{array}{c}65.7( \pm 9.5) \\
\text { [median age: } 66 \text { ] }\end{array}$ \\
\hline $\begin{array}{l}\text { Gastric cancer }(n=52 ; \\
1.8 \%)\end{array}$ & $42(80.8 \%)$ & $10(19.2 \%)$ & $\begin{array}{c}66.7( \pm 12.5) \\
\text { [median age: } 68 \text { ] }\end{array}$ \\
\hline $\begin{array}{l}\text { Duodenal cancer } \\
(n=3 ; 0.1 \%)\end{array}$ & $3(100 \%)$ & $0(0.2 \%)$ & $\begin{array}{c}45.7 \text { ( } \pm 23.6) \\
\text { [median age: } 44]\end{array}$ \\
\hline $\begin{array}{l}\text { Achalasia cardia }(n=3 \\
; 0.1 \%)\end{array}$ & $2(66.7 \%)$ & $1(33.3 \%)$ & $62.0( \pm 10.4)$ \\
\hline $\begin{array}{l}\text { Hiatus hernia ( } n=8 \text {; } \\
0.3 \%)\end{array}$ & $5(62.5 \%)$ & $3(37.5 \%)$ & $45.9( \pm 19.2)$ \\
\hline $\begin{array}{l}\text { Duodenal } \\
\text { diverticulum ( } n=4 \text {; } \\
0.1 \% \text { ) }\end{array}$ & $3(75 \%)$ & $1(25 \%)$ & $50.5( \pm 19.3)$ \\
\hline $\begin{array}{l}\text { Esophageal stricture } \\
(n=2 ; 0.1 \%)\end{array}$ & $1(50 \%)$ & $1(50 \%)$ & $66.5( \pm 7.8)$ \\
\hline
\end{tabular}

Table 2: Distribution of different diagnosis according to the age group

\begin{tabular}{|c|c|c|c|c|c|c|c|}
\hline \multirow[b]{2}{*}{$\begin{array}{c}\text { Total } \\
(\mathrm{N}=2820)\end{array}$} & \multicolumn{7}{|c|}{ Age groups } \\
\hline & $\begin{array}{c}<20 \\
\text { years } \\
(n=99)\end{array}$ & $\begin{array}{c}20-29 \\
\text { years } \\
(n=494)\end{array}$ & $\begin{array}{c}\text { 30-39 } \\
\text { years } \\
(n=490)\end{array}$ & $\begin{array}{c}\begin{array}{c}40-49 \\
\text { years } \\
(n=522)\end{array}\end{array}$ & $\begin{array}{c}50-59 \\
\text { years } \\
(n=462)\end{array}$ & $\begin{array}{c}60-69 \\
\text { years } \\
(n=405)\end{array}$ & $\begin{array}{c}\geq 70 \\
\text { years } \\
(n=348)\end{array}$ \\
\hline $\begin{array}{l}\text { Normal } \\
(n=578 ; \\
20.5 \%)\end{array}$ & $\begin{array}{c}37 \\
(37.4 \%)\end{array}$ & $\begin{array}{c}174 \\
(35.2 \%)\end{array}$ & $\begin{array}{c}119 \\
(24.3 \%)\end{array}$ & $\begin{array}{c}97 \\
(18.6 \%)\end{array}$ & 69 (14.9) & $\begin{array}{c}54 \\
(13.3 \%)\end{array}$ & $28(8 \%)$ \\
\hline $\begin{array}{l}\text { Esophagitis } \\
(n=287 ; \\
10.2 \%)\end{array}$ & $\begin{array}{c}10 \\
(10.1 \%)\end{array}$ & $\begin{array}{c}25 \\
(5.1 \%)\end{array}$ & $\begin{array}{c}25 \\
(5.1 \%)\end{array}$ & $\begin{array}{c}64 \\
(12.3 \%)\end{array}$ & $\begin{array}{c}56 \\
(12.1 \%)\end{array}$ & $\begin{array}{c}66 \\
(16.3 \%)\end{array}$ & $\begin{array}{c}41 \\
(11.8 \%)\end{array}$ \\
\hline $\begin{array}{l}\text { Gastritis and } \\
\text { or duodenitis } \\
\text { (n=1688; } \\
59.9 \% \text { ) }\end{array}$ & $\begin{array}{c}47 \\
(47.5 \%)\end{array}$ & $\begin{array}{c}269 \\
(54.5 \%)\end{array}$ & $\begin{array}{c}324 \\
(66.1 \%)\end{array}$ & $\begin{array}{c}328 \\
(62.8 \%)\end{array}$ & $\begin{array}{c}287 \\
(62.1 \%)\end{array}$ & $\begin{array}{c}225 \\
(55.6 \%)\end{array}$ & $\begin{array}{c}208 \\
(59.8 \%)\end{array}$ \\
\hline $\begin{array}{l}\text { Gastric ulcer } \\
(n=82 ; 2.9 \%)\end{array}$ & $2(2 \%)$ & $9(1.8 \%)$ & $5(1 \%)$ & $\begin{array}{c}12 \\
(2.3 \%)\end{array}$ & $\begin{array}{c}13 \\
(2.8 \%)\end{array}$ & $\begin{array}{c}24 \\
(5.9 \%)\end{array}$ & $\begin{array}{c}17 \\
(4.9 \%)\end{array}$ \\
\hline $\begin{array}{l}\text { Duodenal } \\
\text { ulcer ( } n=59 \text {; } \\
2.1 \%)\end{array}$ & $1(1 \%)$ & $\begin{array}{c}14 \\
(2.8 \%)\end{array}$ & $7(1.4 \%)$ & $\begin{array}{c}10 \\
(1.9 \%)\end{array}$ & $\begin{array}{c}13 \\
(2.8 \%)\end{array}$ & $5(1.2 \%)$ & $9(2.6 \%)$ \\
\hline $\begin{array}{l}\text { Gastric polyp } \\
(n=24 ; 0.9 \%)\end{array}$ & $2(2 \%)$ & $1(0,2 \%)$ & $6(1.2 \%)$ & $1(0.2 \%)$ & $4(0.9 \%)$ & $6(1.5 \%)$ & $4(1.1 \%)$ \\
\hline $\begin{array}{l}\text { Duodenal } \\
\text { polyp ( } n=5 ; \\
0.2 \%)\end{array}$ & $0(0 \%)$ & $0(0 \%)$ & $0(0 \%)$ & $1(0.2 \%)$ & $2(0.4 \%)$ & $2(0.5 \%)$ & $0(0 \%)$ \\
\hline $\begin{array}{l}\text { Esophageal } \\
\text { cancer }(n=25 \text {; } \\
0.9 \%)\end{array}$ & $0(0 \%)$ & $0(0 \%)$ & $0(0 \%)$ & $1(0.2 \%)$ & $4(0.9 \%)$ & $\begin{array}{c}10 \\
(2.5 \%)\end{array}$ & $\begin{array}{c}10 \\
(2.9 \%)\end{array}$ \\
\hline $\begin{array}{l}\text { Gastric } \\
\text { cancer ( } n=52 ; \\
1.8 \%)\end{array}$ & $0(0 \%)$ & $0(0 \%)$ & $0(0 \%)$ & $4(0.8 \%)$ & $\begin{array}{c}12 \\
(2.6 \%)\end{array}$ & $\begin{array}{c}10 \\
(2.5 \%)\end{array}$ & $\begin{array}{c}26 \\
(7.5 \%)\end{array}$ \\
\hline $\begin{array}{l}\text { Duodenal } \\
\text { cancer ( } n=3 \text {; } \\
0.1 \% \text { ) }\end{array}$ & $0(0 \%)$ & $1(0.2 \%)$ & $0(0 \%)$ & $1(0.2 \%)$ & $0(0 \%)$ & $0(0 \%)$ & $1(0.3 \%)$ \\
\hline $\begin{array}{l}\text { Achalasia } \\
\text { cardia ( } n=3 \text {; } \\
0.1 \%)\end{array}$ & $0(0 \%)$ & $0(0 \%)$ & $0(0 \%)$ & $0(0 \%)$ & $1(0.2 \%)$ & $2(0.5 \%)$ & $0(0 \%)$ \\
\hline $\begin{array}{l}\text { Hiatus hernia } \\
(n=8 ; 0.3 \%)\end{array}$ & $0(0 \%)$ & $1(0.2 \%)$ & $3(0,6 \%)$ & $2(0.4 \%)$ & $0(0 \%)$ & $0(0 \%)$ & $2(0.6 \%)$ \\
\hline $\begin{array}{l}\text { Duodenal } \\
\text { diverticulum } \\
\text { ( } n=4 ; 0.1 \%)\end{array}$ & $0(0 \%)$ & $0(0 \%)$ & $1(0.2 \%)$ & $1(0.2 \%)$ & $1(0.2 \%)$ & $0(0 \%)$ & $1(0.3 \%)$ \\
\hline $\begin{array}{l}\text { Esophageal } \\
\text { stricture } \\
(n=2 ; 0.1 \%)\end{array}$ & $0(0 \%)$ & $0(0 \%)$ & $0(0 \%)$ & $0(0 \%)$ & $0(0 \%)$ & $1(0.2 \%)$ & $1(0.3 \%)$ \\
\hline
\end{tabular}


The overall prevalence of $H$. pylori infection was 29.4\%; the males had $29.2 \%$ and females had $29.6 \%$ of $H$. pylori, showing the similar distribution of $H$. pylori among the gender (table 3 ).

The prevalence of $H$. pylori in $\geq 20$ years age group $(20-29$ years $24.7 \%$, 30-39 years $29.2 \%$, $40-49$ years $32.2 \%$, 50-59 years $34.6 \%, 60-69$ years $27.4 \%$ and $\geq 70$ years $31 \%$ ) was greater than that in $<20$ years age group (17.2\%), which was statistically significant $(P=0.001)$ [table 4 ].

The $H$. pylori infection was significantly associated with gastritis and or duodenitis $[\mathrm{P}<0.001$; Odds Ratio (OR) 1.53, 95\% Confidence Interval $(\mathrm{Cl})$ 1.47-1.59], gastric ulcer $(\mathrm{P}<0.001$; OR 18.62, 95\% Cl 12.40-27.81), duodenal ulcer $(\mathrm{P}<0.001 ;$ OR $48.89,95 \% \mathrm{Cl} 25.23-94.75)$, gastric polyp $(\mathrm{P}=0.001 ; \mathrm{OR} 7.66,95 \% \mathrm{Cl} 3.18-18.44)$ and gastric cancer $(\mathrm{P}=0.005$; OR $3.78,95 \% \mathrm{Cl} 1.82-7.86)$, but the association of $H$. pylori with esophagitis seems to be inverse $(\mathrm{P}=0.058$; OR $0.35,95 \% \mathrm{Cl} 0.09-1.29)$. All gastric cancer patients were of non-cardia adenocarcinoma. The gastric polyps were of fundic-gland polyp (12.5\%), hyperplastic polyp (50\%) and adenomatous polyp (37.5\%); among them, 1 patient of hyperplastic polyp and 4 patients of adenomatous polyp had positive $H$. pylori, and pathological feature of gastric mucosa showed that 3 patients of hyperplastic polyp $(H$. pylori positive 1 ) and 5 patients of adenomatous polyp (H. pylori positive 2 ) had atrophic gastritis with intestinal metaplasia. The distribution of different types of gastric polyps is given in table 6 .

Table 3: Distribution of $\boldsymbol{H}$. pylori according to the gender

\begin{tabular}{lccc}
\hline & $\begin{array}{c}\text { H. pylori } \\
\text { positive }\end{array}$ & $\begin{array}{c}\text { H. pylori } \\
\text { negative }\end{array}$ & $\begin{array}{c}\text { P } \\
\text { value }\end{array}$ \\
\hline Male $(n=1529)$ & $446(29.2 \%)$ & $1083(70.8 \%)$ & \\
Female $(n=1291)$ & $382(29.6 \%)$ & $909(70.4 \%)$ & 0.80 \\
\hline
\end{tabular}

Table 4: Distribution of $\boldsymbol{H}$. pylori according to the age group

\begin{tabular}{|c|c|c|c|c|c|c|c|c|}
\hline \multirow[b]{2}{*}{$\begin{array}{l}\text { Total } \\
(\mathrm{N}=2820)\end{array}$} & \multicolumn{8}{|c|}{ Age groups } \\
\hline & $\begin{array}{c}<20 \\
\text { years } \\
(n=99)\end{array}$ & $\begin{array}{c}20-29 \\
\text { years } \\
(n=494)\end{array}$ & $\begin{array}{c}30-39 \\
\text { years } \\
(n=490)\end{array}$ & $\begin{array}{c}40-49 \\
\text { years } \\
(n=522)\end{array}$ & $\begin{array}{c}50-59 \\
\text { years } \\
(n=462)\end{array}$ & $\begin{array}{c}60-69 \\
\text { years } \\
(n=405)\end{array}$ & $\begin{array}{c}\geq 70 \\
\text { years } \\
(n=348)\end{array}$ & $\begin{array}{c}P \\
\text { value }\end{array}$ \\
\hline \multicolumn{9}{|l|}{ H. pylori } \\
\hline $\begin{array}{l}\text { Positive } \\
\text { (n=829; } \\
29.4 \%)\end{array}$ & $\begin{array}{c}17 \\
(17.2 \%)\end{array}$ & $\begin{array}{c}122 \\
(24.7 \%)\end{array}$ & $\begin{array}{c}143 \\
(29.2 \%)\end{array}$ & $\begin{array}{c}168 \\
(32.2 \%)\end{array}$ & $\begin{array}{c}160 \\
(34.6 \%)\end{array}$ & $\begin{array}{c}111 \\
(27.4 \%)\end{array}$ & $\begin{array}{c}108 \\
(31 \%)\end{array}$ & \\
\hline H. pylori & & & & & & & & 0.001 \\
\hline $\begin{array}{l}\text { Negative } \\
\text { (n=1991; } \\
70.6 \%)\end{array}$ & $\begin{array}{c}82 \\
(82.8 \%)\end{array}$ & $\begin{array}{c}372 \\
(75.3 \%)\end{array}$ & $\begin{array}{c}347 \\
(70.8 \%)\end{array}$ & $\begin{array}{c}354 \\
(67.8 \%)\end{array}$ & $\begin{array}{c}302 \\
(65.4 \%)\end{array}$ & $\begin{array}{c}294 \\
(72.6 \%)\end{array}$ & $\begin{array}{c}240 \\
(69 \%)\end{array}$ & \\
\hline
\end{tabular}

The distribution of $H$. pylori infection among different diagnosis was as follows: normal $2.6 \%$, esophagitis $0.7 \%$, gastritis and or duodentis $41.1 \%$, gastric ulcer $69.5 \%$, duodenal ulcer $84.7 \%$, gastric polyp $20.8 \%$, duodenal polyp $0 \%$, esophageal cancer $0 \%$, gastric cancer $11.5 \%$, duodenal cancer $0 \%$, achalasia cardia $0 \%$, hiatus hernia $0 \%$, duodenal diverticulum $0 \%$ and esophageal stricture $0 \%$ (table 5 ).

Table 5: Distribution of $\boldsymbol{H}$. pylori according to the different diagnosis

\begin{tabular}{|c|c|c|c|c|}
\hline Total $(\mathrm{N}=\mathbf{2 8 2 0})$ & $\begin{array}{l}\text { H. pylori } \\
\text { positive }\end{array}$ & $\begin{array}{l}\text { H. pylori } \\
\text { negative }\end{array}$ & $\begin{array}{c}P \\
\text { value* }\end{array}$ & $\begin{array}{l}\text { Odds Ratio } \\
(* * 95 \% \text { Cl) }\end{array}$ \\
\hline Normal $(n=578)$ & $15(2.6 \%)$ & $563(97.4 \%)$ & & \\
\hline Esophagitis ( $n=287$ ) & $2(0.7 \%)$ & $285(99.3 \%)$ & 0.058 & $0.35(0.09-1.29)$ \\
\hline $\begin{array}{l}\text { Gastritis and or } \\
\text { duodenitis ( } n=1688 \text { ) }\end{array}$ & $693(41.1 \%)$ & 995 (58.9\%) & $<0.001$ & $1.53(1.47-1.59)$ \\
\hline Gastric ulcer ( $n=82$ ) & $57(69.5 \%)$ & $25(30.5 \%)$ & $<0.001$ & $18.62(12.40-27.81)$ \\
\hline Duodenal ulcer ( $n=59$ ) & $50(84.7 \%)$ & $9(15.3 \%)$ & $<0.001$ & $48.89(25.23-94.75)$ \\
\hline Gastric polyp ( $n=24)$ & $5(20.8 \%)$ & $19(79.2 \%)$ & 0.001 & 7.66 (3.18-18.44) \\
\hline Duodenal polyp ( $n=5$ ) & $0(0 \%)$ & $5(100 \%)$ & 1.0 & \\
\hline Esophageal cancer ( $n=25$ ) & $0(0 \%)$ & $25(100 \%)$ & 1.0 & \\
\hline Gastric cancer ( $n=52$ ) & $6(11.5 \%)$ & $46(88.5 \%)$ & 0.005 & $3.78(1.82-7.86)$ \\
\hline Duodenal cancer $(n=3)$ & $0(0 \%)$ & $3(100 \%)$ & 1.0 & \\
\hline Achalasia cardia $(n=3)$ & $0(0 \%)$ & $3(100 \%)$ & 1.0 & \\
\hline Hiatus hernia $(n=8)$ & $0(0 \%)$ & $8(100 \%)$ & 1.0 & \\
\hline $\begin{array}{l}\text { Duodenal diverticulum } \\
(n=4)\end{array}$ & $0(0 \%)$ & $4(100 \%)$ & 1.0 & \\
\hline $\begin{array}{l}\text { Esophageal stricture } \\
(n=2)\end{array}$ & $0(0 \%)$ & $2(100 \%)$ & 1.0 & \\
\hline
\end{tabular}

$\wedge$ Patients with normal endoscopic findings were taken as the control group

* P value obtained using Chi square test or Fischer exact test as appropriate

$* * 95 \%$ Confidence Interval

Table 6: Distribution of different types of gastric polyps

\begin{tabular}{lcccc}
\hline \multicolumn{1}{c}{ Polyps (N=24) } & $\begin{array}{l}\text { H. pylori } \\
\text { positive }\end{array}$ & $\begin{array}{c}\text { H. pylori } \\
\text { negative }\end{array}$ & Total & $\begin{array}{c}\text { P } \\
\text { value* }\end{array}$ \\
\hline Fundic-gland polyp & $0(0 \%)$ & $3(15.8 \%)$ & $3(12.5 \%)$ & \\
Hyperplastic polyp: & $1(20 \%)$ & $11(57.9 \%)$ & $12(50 \%)$ & \\
$\begin{array}{l}\text { Atrophic gastritis with intestinal } \\
\text { metaplasia (n=3) }\end{array}$ & 1 & 2 & & 0.083 \\
$\begin{array}{l}\text { Adenomatous polyp: } \\
\text { Atrophic gastritis with intestinal }\end{array}$ & $4(80 \%)$ & $5(26.3 \%)$ & $9(37.5 \%)$ & \\
metaplasia (n=5) & 2 & 3 & & \\
\hline
\end{tabular}

* $\mathrm{P}$ value obtained using Chi square test or Fischer exact test as appropriate

The crude and age-standardized (world) annual rates of gastric cancer in Kaski district of Nepal were 2.5 and 3.3 per 100,000 
world population, respectively during the three year period of 2010-2013.

The age-standardized (world) incidence of gastric cancer per 100,000 during the year 2010-2013, calculated according to the age wise population distribution of Kaski district of Nepal is shown in table 7.

Table 7: Age-standardized (world) incidence of gastric cancer per 100,000 in Nepal during the year 2010-2013.

\begin{tabular}{lccc}
\hline $\begin{array}{c}\text { Age } \\
\text { group } \\
\text { (Years) }\end{array}$ & $\begin{array}{c}\text { No. of } \\
\text { gastric } \\
\text { cancers }\end{array}$ & $\begin{array}{c}\text { Population of Kaski district } \\
\text { of Nepal according to the } \\
\text { age group }\end{array}$ & $\begin{array}{c}\text { Age-standardized (world) } \\
\text { incidence rate of gastric } \\
\text { cancer in Nepal per 100,000 }\end{array}$ \\
\hline $40-49$ & 4 & 47523 & 0.3 \\
$50-59$ & 12 & 34727 & 0.8 \\
$60-69$ & 10 & 23423 & 0.6 \\
270 & 26 & 19512 & 1.6 \\
Total age-standardized (world) incidence rate of \\
gastric cancer in Nepal per 100,000
\end{tabular}

\section{DISCUSSION}

More than half of patients referred for endoscopy had gastritis and or duodenitis, although one fifth patients had normal findings and one tenth patients had esophagitis; the prevalence of peptic ulcer disease was $5 \%$, gastric cancer $1.8 \%$ and esophageal cancer $0.9 \%$ showing that the gap between peptic ulcer and malignancy was not big.

The median age of presentation of gastric cancer and esophageal cancer was more than 65 years, but that of duodenal cancer was only 44 years, which may not be truly representative of that group of patients, because of the low sample size (three) of duodenal cancer.

The actual $H$. pylori infection rate varies not only between different countries, but also according to the different geographic area of the same country, patient age and socioeconomic status. ${ }^{16,17}$

The H.pylori prevalence in developing countries is much higher than the developed countries, which may be due to higher socioeconomic status and improvements in hygiene practices. ${ }^{17}$

Nepal is a small landlocked South Asian developing country with an area of 147,181 square kilometers ${ }^{14}$ and has got almost similar socio-cultural background with the other South Asian developing countries like India and Bangladesh. In India, the seroprevalence of $H$. pylori was estimated to be $79 \%$ (sample size 238 ) in 1991 and 67\% (sample size 340 ) in $1994 .{ }^{18,19}$ In
Bangladesh, the $H$. pylori prevalence was estimated to be 91.7\% (sample size 181) in 1997 and 69.7\% (sample size 241) in $2003 . .^{20,21}$ In one study done in Nepal in 1998, the overall seroprevalence of $H$. pylori infection was estimated to be $56.8 \%$ (sample size 1142), with lower rate of $41.5 \%$ in an isolated rural village. ${ }^{22}$

These studies have given an overall impression of very high prevalence of $H$. pylori in this part of developing world and inadequate sanitation practices, low social class, and crowded or high-density living conditions have been attributed to the higher prevalence of $H$. pylori infection. ${ }^{23}$ However, the retrospective study done in Nepal in 2005 showed that the prevalence of $H$. pylori was $33.9 \%$ (sample size 224 ) in dyspeptic patients attending the hospital. ${ }^{24}$ The finding was almost similar with slightly decreasing prevalence by $4.4 \%$ in another study done in Nepal one year after in 2006 with $H$. pylori prevalence of $29.5 \%$ (sample size 203). ${ }^{25}$ Our current study done in Nepal with more sample size (2820) also demonstrated the similar result with $H$. pylori prevalence of $29.4 \%$. This indicates that the prevalence of $H$. pylori in developing South Asian countries in the current era might not be very high as was projected from a decade old data. This could be due to the development of the 'westernization' of the life style in those developing countries, which have witnessed increasing prevalence of other diseases of affluent society such as type 2 diabetes. ${ }^{26}$ Another potential reason for this decreasing trend of $H$. pylori prevalence could be due to the widespread use of proton pump inhibitors and antibiotics.

One study done in 1998 had used saliva specimen for the diagnosis of $H$. pylori in remote areas of Nepal in two villages Tarap (altitude $3600 \mathrm{~m}$ ) and Ringmo (altitude $4100 \mathrm{~m}$ ), and showed low $H$. pylori prevalence of only $11.6 \%(n=62)$ in Ringmo village and none in Tarap village $(n=38) .{ }^{27}$ The study had limitations because of the flaws in the transport of the saliva sample and the sample size was very low. However, the study had emphasized about the need of the study of genetics of bacteria found in remote population because of the exquisite adaptation of $H$. pylori to its host. ${ }^{28}$ This may unleash the diverse behavior of $H$. pylori in the population of remote Nepal showing the altered epidemiology H. pylori in Nepal.

The study done in China showed that the seroprevalence of H. pylori infection was significantly decreased during the 10year period in Guangzhou, with the overall age-standardized H. pylori seroprevalence rate being $62.5 \%$ in 1993 and $49.3 \%$ in 2003. ${ }^{29}$ The decreasing trend of $H$. pylori prevalence was also shown by several other Asian studies. ${ }^{30-32}$ The $H$. pylori seroprevalence rate was $74.6 \%$ in Vietnam, $58.07 \%$ in China, $39.3 \%$ in Japan, $59.6 \%$ in South Korea, 54.5\% in Taiwan, 35.9\% in Malaysia, $31 \%$ in Singapore and $57 \%$ in Thailand. ${ }^{33-40}$ On the other hand, the seroprevalence rates in more developed 
countries were generally lower with the overall seroprevalence rate of $15.1 \%$ in Australia. ${ }^{41}$ In the United States, H. pylori prevalence varied with different ethnic groups with the prevalence of $60 \%$ in Hispanics, $54 \%$ in African Americans, and $20 \%$ in whites. ${ }^{42}$

One study done in UK showed that the risk of $H$. pylori infection was increased in male gender, living with a partner and poor adult socioeconomic conditions. ${ }^{43}$

However, our study didn't show any significant difference of $H$. pylori prevalence among the gender. This was consistent with the findings of some studies, which did not find gender-related difference in the prevalence of $H$. pylori infection. ${ }^{44-46}$

In our study, the age group $<20$ years had lower prevalence (17.2\%) of $H$. pylori than that of $\geq 20$ years group, which showed the highest prevalence (34.6\%) being seen in the age group of 50-59 years followed by higher prevalence $(32.2 \%)$ in 40-49 years group. This difference in $H$. pylori prevalence among different age group was statistically significant and this again showed the changing epidemiology of $H$. pylori in developing countries, which now seem to be following the pattern of developed countries, showing the rising trend of the prevalence of infection with age during adulthood. ${ }^{47}$

The prevalence of $H$. pylori-related diseases also varies in different geographic regions and patient populations. ${ }^{8}$

Our study showed that $H$. pylori was significantly associated not only with gastritis and or duodenitis and peptic ulcers, but also with the gastric polyp. The patients with combined gastric polyp and $H$. pylori might be high risk factor for gastric cancer. Hence, all the patients with gastric polyp might need to be investigated for $H$. pylori and if both are present, the triple therapy regimen for the eradication of $H$. pylori along with the removal of polyp would be more appropriate to prevent the gastric cancer.

The previous so-called Asian enigma of very high prevalence of $H$. pylori associated with low prevalence of gastric cancer was not obvious in our study, which showed only $29.4 \%$ of H. pylori prevalence and $1.8 \%$ of gastric cancer. The gastric cancer was associated with $H$. pylori positivity in $11.7 \%$ which was statistically significant when compared to $2 \%$ of $H$. pylori positivity in subjects with normal endoscopic findings taken as the controls, giving an OR of 3.78 (95\% Cl 1.82-7.86); the median age of gastric cancer patients was 68 years. This was in contrast to the study from Japan where overall OR for gastric cancer was high in younger age with OR of 7.0 for aged 2029 and 14.5 for aged 40-49; on the other hand, OR was much lower in elderly group, with OR of 3.5 for aged 50-59 and 1.5 for 60-69, which was almost similar to our study. ${ }^{48}$ This Japanese study showed that the higher seroprevalence was shown in early cancer than advanced cancer, especially in older subjects, and lower seroprevalence in elderly could be due to seroreversion. ${ }^{48}$

Another study form Japan, in which 123576 subjects were followed up from 1990 to 2004 with 511 gastric cancer cases, showed adjusted $\mathrm{OR}$ for gastric cancer associated with $H$. pylori of 5.1. ${ }^{49}$ The age-standardized (world) annual incidence rate of gastric cancer in Kaski district of Nepal was found to be 3.3 per 100,000 population which was consistent with the data from Delhi of India (3.4 per 100,000), but the OR of gastric cancer associated with $H$. pylori in Delhi was only 1.5 than controls. ${ }^{50}$ One study done in 2009 showed that the multiinstitution hospital-based incidence of gastric cancer in Nepal was found to be $7.5 \%$ in male and $4.1 \%$ in female among all recorded cancer patients. ${ }^{51}$

The gastric cancer epidemiology has been categorized as high-risk areas (East Asian countries such as China, Japan and Korea), where the age-standardized incidence rate is greater than 20 per 100 000, intermediate risk areas (Malaysia, Singapore and Taiwan) with that of 11-20/100 000 and lowrisk areas (Australia, New Zealand, India and Thailand) with that of $<10 / 100000 .{ }^{17}$ According to this categorization, Nepal falls in the low-risk area of gastric cancer incidence.

However, our study was not without limitations. Some of the subjects, who might have consumed the drugs such as proton pump inhibitors or histamine 2-receptor antagonists 2 weeks prior to the test and antibiotics 4 weeks prior to the enrollment in the study, without the knowledge of the investigator, were supposed be excluded from the study, but might have been included because of the sampling error, resulting in the inappropriate $H$. pylori results. Our study did not collect the data on education, monthly income, household size and other variables, and hence, the association of these variables with $H$. pylori could not be assessed. While assessing the incidence of gastric cancers in Kaski district of Nepal, some undiagnosed and unnoticed cases beyond the reach of the investigator, might have been missed and it is difficult to project the incidence of one district to generalize for the country as a whole. Despite these shortcomings, the findings of $H$. pylori prevalence in our study is more robust compared to most other studies of $H$. pylori prevalence based on serology, because our prevalence rates are of active infections and based upon the detection of $H$. pylori on histopathology. The other $H$. pylori prevalence studies done with serology test do not differentiate between active or previous infection. Moreover, the gastric cancer incidence rate and its potential association with $\mathrm{H}$. pylori have been determined for the first time in Nepal.

In conclusion, the $H$. pylori prevalence in Nepal was lower than that shown in the previous studies of developing 
Asian countries, but was significantly high in gastritis and or duodenitis, and peptic ulcers. Moreover, the gastric cancer incidence was also low in Nepal, but was significantly associated with $H$. pylori. However, further study is needed to establish the potential association of $H$. pylori with gastric cancer in Nepal before recommending $H$. pylori eradication as a means of gastric cancer preventive measure.

relation to socioeconomic status despite a uniformly high prevalence in adults. Am J Epidemiol 1996;143:257262.

11. Nomura A, Stemmermann GN, Chyou PH et al. Helicobacter pylori infection and gastric carcinoma among Japanese-Americans in Hawaii. N Engl J Med 1991;325:1132-1136.

12. Kikuchi S, Wada O, Nakajima $T$ et al. Serum antiHelicobacter pylori antibody and gastric carcinoma among young adults. Cancer 1995;75:2789-2793.

13. World Gastroenterology Organisation Global Guideline. Helicobacter pylori in Developing Countries. J Dig Dis 2011;12; 319-326.

14. National Population and Housing Census 2011. Central Bureau of Statistics, Kathmandu, Nepal. NPHC 2011:2

15. Population Reference Bureau. World Population data Sheet 2012.

16. Tanih NF, Ndip LM, Clarke AM et al. An overview of pathogenesis and epidemiology of Helicobacter pylori infection. Afr J Microbiol Res 2010;4:426-436.

17. Fock KM, Ang TL. Epidemiology of Helicobacter pylori infection and gastric cancer in Asia. J Gastroenterol Hepatol 2010; 25:479-486.

18. Graham DY, Adam E, Reddy GT et al. Seroepidemiology of Helicobacter pylori infection in India. Dig Dis Sci 1991;36:1084-1088.

19. Gill HH, Majmudar P, Shankaran K et al. Age-related prevalence of Helicobacter pylori antibodies in Indian subjects. Indian J Gastroenterol 1994;13:92-94.

20. Ahmad MM, Rahman M, Rumi AK et al. Prevalence of Helicobacter pylori in asymptomatic population--a pilot serological study in Bangladesh. J Epidemiol 1997;7:251254.

21. Lee CS, Kim DY, Jung CW et al. Prevalence of Helicobacter pylori in Bangladesh: Rapid urease test. The ORION Medical Journal

10. Malaty HM, Kim JG, Kim SD, et al. Prevalence of Helicobacter pylori infection in Korean children: inverse 
2003;16:104-105.

22. Kawasaki M, Kawasaki T, Ogaki T et al. Seroprevalence of Helicobacter pylori infection in Nepal: low prevalence in an isolated rural village. Eur J Gastroenterol Hepatol 1998;10:47-50.

23. Brown LM. Helicobacter pylori: Epidemiology and Routes of Transmission. Epidemiol Rev 2000:22;283-297.

24. Makaju RK, Tamang MD, Sharma Y et al. Prevalence of Helicobacter pylori in Dhulikhel Hospital, Kathmandu University Teaching Hospital: a retrospective histopathologic study. Kathmandu Univ Med J (KUMJ). 2005;3:355-359.

25. Rai SK, Shah RD, Bhattachan $\mathrm{CL}$ et al. Helicobacter pylori associated gastroduodenal problem among the Nepalese. Nepal Med Coll J 2006;8:9-13.

26. Shrestha UK, Singh DL, Bhattarai MD. The prevalence of hypertension and diabetes defined by fasting and 2-h plasma glucose criteria in urban Nepal. Diabet Med 2006;23:1130-1135.

27. Bupperex G BB, Megraud F. Saliva specimens for diagnosis of Helicobacter pylori obtained in remote areas of Nepal. Lancet 1999;354:1529-1530.

28. Blaser MJ. The versatility of Heliocobacter pylori in the adaptation to the human stomach. J Physiol Pharmacol 1997; 48:307-314.

29. Chen J, Bu XL, Wang QY et al. Decreasing seroprevalence of Helicobacter pylori infection during 1993-2003 in Guangzhou, southern China. Helicobacter 2007;12:164169.

30. Wong SN, Sollano JD, Chan MM et al. Changing trends in peptic ulcer prevalence in a tertiary care setting in the Philippines: a seven year study. J Gastroenterol Hepatol 2005;20:628-632.

31. Ho KY, Chan YH, Kang JY. Increasing trend of reflux Esophagitis and decreasing trend of Helicobacter pylori infection in patients from a multiethnic Asian country. Am J Gastroenterol 2005;100:1923-1928.

32. Xia B, Xia HH, Ma CW et al. Trends in the prevalence of peptic ulcer disease and Helicobacter pylori infection in family physician-referred uninvestigated dyspeptic patients in Hong Kong. Aliment Pharmacol Ther
2005;22:243-249.

33. Hoang TT, Bengtsson C, Phung DC et al. Seroprevalence of Helicobacter pylori infection in urban and rural Vietnam. Clin Diagn Lab Immunol 2005;12: 81-85.

34. Wang KJ, Wang RT. Meta-analysis on the epidemiology of Helicobacter pylori infection in China. Zhonghua Liu Xing Bing Xue Za Zhi 2003;24:443-6.

35. Fujisawa T, Kumagai T, Akamatsu $\mathrm{T}$ et al. Changes in seroepidemiological pattern of Helicobacter pylori and hepatitis A virus over the last 20 years in Japan. Am J Gastroenterol. 1999; 94:2094-2099.

36. Yim JY, Kim N, Choi SH et al. Seroprevalence of Helicobacter pylori in South Korea. Helicobacter 2007;12:333-340.

37. Teh BH, Lin JT, Pan WH et al. Seroprevalence and associated risk factors of Helicobacter pylori infection in Taiwan. Anticancer Res 1994;14:1389-1392.

38. Goh KL, Parasakthi N. The racial cohort phenomenon: seroepidemiology of Helicobacter pylori infection in a multiracial South-East Asian country. Eur J Gastroenterol Hepatol. 2001;13:177-83.

39. Fock KM. Helicobacter pylori infection-current status in Singapore. Ann Acad Med Singapore 1997;26:637-641.

40. Deankanob W, Chomvarin C, Hahnvajanawong C et al. Enzyme-linked immunosorbent assay for serodiagnosis of Helicobacter pylori in dyspeptic patients and volunteer blood donors. Southeast Asian J Trop Med Public Health 2006;37:958-965.

41. Moujaber $\mathrm{T}$, Maclntyre $\mathrm{CR}$, Backhouse J et al. The seroepidemiology of Helicobacter pylori infection in Australia. Int J Infect Dis 2008;12:500-504.

42. Everhart JE, Kruszon-Moran D, Perez-Perez GI et al. Seroprevalence and ethnic differences in Helicobacter pylori infection among adults in the United States. J Infect Dis 2000;181:1359-1363. 43. Moayyedi P, Axon AT, Feltbower R et al. Relation of adult lifestyle and socioeconomic factors to the prevalence of Helicobacter pylori infection. Int J Epidemiol 2002;31:624-631.

44. Goh KL. Prevalence of and risk factors for Helicobacter pylori infection in a multi-racial dyspeptic Malaysian 
population undergoing endoscopy. J Gastroenterol Hepatol 1997,12:S29-35.

45. Fraser AG, Scragg $R$, Metcalf $P$ et al. Prevalence of Helicobacter pylori infection in different ethnic groups in New Zealand children and adults. Aust N Z J Med 1996,26:646-651.

46. Begue RE, Gonzales JL, Correa-Gracian H et al. Dietary risk factors associated with the transmission of Helicobacter pylori in Lima, Peru. Am J Trop Med Hyg 1998,59:637640.

47. Pounder RE, Ng D. The prevalence of Helicobacter pylori infection in different countries. Aliment Pharmacol Ther 1995;9:33-39.

48. Kikuchi S, Nakajima T, Kobayashi O et al. Effect of age on the relationship between gastric cancer and Helicobacter pylori. Tokyo Research Group of Prevention for Gastric Cancer. Jpn J Cancer Res 2000;91:774-779.

49. Sasazuki S, Inoue M, Iwasaki M et al. Effect of Helicobacter pylori infection combined with CagA and pepsinogen status on gastric cancer development among Japanese men and women: a nested case-control study. Cancer Epidemiol Biomarkers Prev 2006;15:1341-1347.

50. Yeole BB. Trends in Cancer Incidence in Esophagus, Stomach, Colon, Rectum and Liver in Males in India. Asian Pacific J Cancer Prev 2008;9:97-100.

51. Pradhananga KK, Baral M, Shrestha BM. Multi-institution hospital-based cancer incidence data for Nepal: an initial report. Asian Pac J Cancer Prev 2009;10:259-262. 